\title{
PERILAKU MASYARAKAT TENTANG PEMAKAIAN GIGI TIRUAN DI DUSUN I DESA TALIKUMAIN KABUPATEN ROKAN HULU
}

\author{
Raviola \\ Program Studi D-III Teknik Gigi \\ Sekolah Tinggi Ilmu Kesehatan (STIKes) Hang Tuah Pekanbaru \\ lo14fiola@yahoo.com
}

\begin{abstract}
ABSTRAK
Behavior is a respond of individuals to a stimulus or an action. In Hamlet I of Talikumain Village, many people who lost their teeth but were not replaced with dentures. The purpose of this research was to know the behavior of the people about the importance of denture usage in Hamlet I of Talikumain Village, Central Tambusai Subdistrict, Rokan Hulu Regency. This research type was quantitave descriptive. The population of people in Hamlet I of Talikumain Village was 547 people and a sample of 85 people. Stratified random sampling technique (proportional random sampling). The result showed that the respondents did not use dentures 78 people (91.8\%), the age of the aerly senior category with 27 people $(31.8 \%)$, the gender of female respondents amounted to 58 people $(68.2 \%)$, the education of elementary respondent Amounting to 37 people (41.2\%), the job of the farmer's respondent 41 people (48.2\%), knowledge of the respondent was good 60 people (70.6\%), the attitude of the respondent good 48 people (52.9\%) Expected to public health institutions in Hamlet I, Talikumain Village can be held socialization of society to add better knoeledge so that people who initially do not want to use dentures becomes want to use a dentures.
\end{abstract}

Keywords : Denture, Characteristics, Behavior

\begin{abstract}
ABSTRAK
Perilaku merupakan respon individu terhadap suatu stimulus atau suatu tindakan. Di Dusun I Desa Talikumain banyak masyarakat yang kehilangan gigi namun tidak diganti dengan gigi tiruan. Tujuan penelitian ini untuk mengetahui perilaku masyarakat tentang pentingnya pemakaian gigi tiruan di Dusun I Desa Talikumain Kecamatan Tambusai Tengah Kabupaten Rokan Hulu. Jenis penelitian ini adalah kuantitatif deskriptif. Populasi masyarakat di Dusun I Desa Talikumain 547 orang dan sampel 85 orang. Teknik pengambilan sampel stratified random sampling (proportional random sampling). Hasil penelitian menunjukkan bahwa responden yang tidak memakai gigi tiruan berjumlah 78 orang (91.8\%), umur responden kategori lansia awal dengan jumlah 27 orang $(31.8 \%)$, jenis kelamin responden perempuan berjumlah 58 orang (68.2\%), pendidikan responden SD berjumlah 37 orang (41.2\%), pekerjaan responden petani 41 orang $(48.2 \%)$, pengetahuan responden baik 60 orang $(70.6 \%)$, sikap responden baik 48 orang (56.4\%) dan tindakan responden baik 45 orang (52.9\%). Diharapkan kepada institusi kesehatan masyarakat di Dusun I Desa Talikumain dapat diadakan sosialisasi masyarakat untuk menambah pengetahuan yang lebih baik lagi agar masyarakat yang awalnya tidak mau menggunakan gigi tiruan menjadi ingin memakai gigi tiruan.
\end{abstract}

Kata Kunci : Gigi Tiruan, Karakteristik, Perilaku

\section{PENDAHULUAN}

Perilaku adalah respon individu terhadap suatu stimulus atau suatu tindakan yang dapat diamati dan mempunyai frekuensi spesifik, durasi dan tujuan baik disadari maupun tidak disadari bahwa interaksi tersebut amat kompleks sehingga kadang-kadang kita tidak sempat memikirkan penyebab seseorang 
menerapkan perilaku tertentu. (A. Wawan dan Dewi M, 2010).

Gigi merupakan salah satu organ penting yang memiliki beberapa fungsi, yaitu fungsi pengunyahan, fungsi bicara, dan fungsi estetik. Gigi yang dimiliki setiap individu berada didalam rongga mulut dan tersusun pada lengkung rahang atas dan rahang bawah. Susunan gigi geligi yang ada bisa saja tidak utuh lagi karena mengalami kehilangan, dan kehilangan yang terjadi tidak memandang usia.

Kehilangan gigi merupakan hal umum yang terjadi pada masyarakat saat ini. Beberapa faktor penghambat dalam penggunaan gigi tiruan antara lain faktor predisposisi.

Angka kehilangan gigi di Indonesia tergolong tinggi yaitusebesar $24 \%$ pada penduduk yang berumur diatas 65 tahun (Amuwarningsih \& Darjono, 2011). Berdasarkan Riset Kesehatan Dasar (RISKESDAS, 2007) di Indonesia persentase kehilangan seluruh gigi terdapat $1,6 \%$. Di provinsi Riau terdapat 2,2\% telah kehilangan seluruh gigi aslinya sedangkan dipekanbaru terdapat $0,6 \%$ yang kehilangan keseluruhan gigi aslinya. Persentase penduduk yang melalukan pemasangan gigi palsu lepasan atau gigi palsu cekat di Indonesia terdapat $4,6 \%$. Di provinsi Riau terdapat $9,7 \%$ dan di kota Pekanbaru terdapat $2,4 \%$ penduduk yang menggunakan pemasangan gigi tiruan atau gigi cekat (RISKESDAS, 2007) (Lusianti, 2018).

Desa Talikumain terletak di

Kabupaten Rokan Hulu Kecamatan Tambusai Tengah dan memiliki luas wilayah $3.337 \mathrm{~km}^{2}$. Perbatasan barat Desa Talikumain adalah Desa Mondang Kumango, perbatasan timur DK 4/ Selarinda. Perbatasan utara Daludalu/Rantau Panjang dan perbatasan selatan adalah Batas. Desa Talikumain mempunyai jumlah penduduk 2.031 orang, terdapat 541 kartu keluarga, 3 Dusun , 7 RW dan 14 RT. Dusun I berjumlah 689 penduduk, di dusun II 288 penduduk dan dusun III 1.054 penduduk.

Observasi awal yang dilakukan di
Dusun I Desa Talikumain Kecamatan Tambusai Tengah Kabupaten Rokan Hulu pada 55 orang masyarakat Dusun I Desa Talikumain, terdapat 29 orang kehilangan gigi namun tidak diganti dengan gigi tiruan, 7 orang yang memakai gigi tiruan, dan 19 orang lainnya tidak kehilangan gigi. Berdasarkan kuesioner yang saya bagikan terhadap 55 orang, pengetahuan masyarakat tentang pemakaian gigi tiruan di Dusun I Desa Talikumain baik (65\%), sikap masyarakatnya juga baik (69\%) dan tindakannya baik (76\%). Dari 55 orang masyarakat Dudun I Desa Talikumain, 42 orang berjenis kelamin perempuan dan 13 orang berjenis kelamin laki- laki. Dan ratarata dari mereka pendidikan terakhirnya adalah SD dan juga rata-rata pekerjaan mereka petani.

\section{METODE}

Metode peneliatian yang digunakan adalah kuantitatif deskriptif. Populasi masyarakat di Dusun I Desa Talikumain yang kehilangan gigi dengan jumlah 547 dan sampel 85 responden. Teknik pengambilan sampel stratified random sampling (proportional random sampling). Alat pengumpulan data menggunakan kuesioner dan analisis yang dilakukan secara univariat. Penelitian dilakukan pada bulan April - Juni 2019.

\section{HASIL}

\section{Gigi Tiruan}

Tabel 1. Distribusi Frekuensi Pemakaian Gigi Tiruan

\begin{tabular}{clcc}
\hline No & $\begin{array}{l}\text { Pemakaian } \\
\text { Gigi Tiruan }\end{array}$ & $\begin{array}{c}\text { Frekuensi } \\
\text { (Orang) }\end{array}$ & $\begin{array}{c}\text { Persentase } \\
\mathbf{( \% )}\end{array}$ \\
\hline 1 & Tidak pakai & 78 & 91.8 \\
2 & Pakai & 7 & 8.2 \\
\hline & Jumlah & 85 & 100 \\
\hline
\end{tabular}

Hasil penelitian tentang pemakaian gigi tiruan pada masyarakat Dusun I Desa Talikumain Kabupaten Rokan Hulu yang terdapat pada tabel 1 terlihat bahwa dari 85 responden sebagian besar yang tidak 
menggunakan gigi tiruan ada 78 orang $(91.8 \%)$.

\section{Umur}

Tabel 2. Distribusi Frekuensi Umur Responden

\begin{tabular}{llcl}
\hline No & \multicolumn{1}{c}{ Umur } & Frekuensi & $\begin{array}{c}\text { Persentase } \\
(\mathbf{\%})\end{array}$ \\
\hline $\mathbf{1}$ & Remaja Akhir $(17-25)$ & 5 & 5.9 \\
$\mathbf{2}$ & Dewasa Awal (26-35) & 9 & 10.6 \\
$\mathbf{3}$ & Dewasa Akhir (36-45) & 20 & 23.5 \\
$\mathbf{4}$ & Lansia Awal (46-55) & 27 & 31.8 \\
$\mathbf{5}$ & Lansia Akhir (56-65) & 17 & 20 \\
$\mathbf{6}$ & Manula (>65) & 7 & 8.2 \\
\hline & Jumlah & 85 & 100 \\
\hline
\end{tabular}

Hasil penelitian mengenai umur yang terlihat pada tabel 2, menunjukkan bahwa dari 85 responden yang diteliti, sebagian besar umur responden masuk dalam kategori lansia awal dengan jumlah 27 orang (31.8\%)

Jenis Kelamin

Tabel 3. Distribusi Frekuensi Jenis Kelamin Responden

\begin{tabular}{llll}
\hline No & $\begin{array}{l}\text { Jenis } \\
\text { Kelamin }\end{array}$ & Frekuensi & $\begin{array}{l}\text { Persentase } \\
(\boldsymbol{\%})\end{array}$ \\
\hline $\mathbf{1}$ & Laki-laki & 27 & 31.8 \\
$\mathbf{2}$ & Perempuan & 58 & 68.2 \\
\hline & Jumlah & 85 & 100 \\
\hline
\end{tabular}

Hasil dari penelitian pada tabel 3 terlihat bahwa dari 85 orang responden yang diteliti, bahwa sebagian besar jenis kelamin responden perempuan dengan jumlah 58 orang $(68.2 \%)$.

\section{Pendidikan}

Tabel 4. Distribusi Frekuensi Pendidikan Responden

\begin{tabular}{llll}
\hline No & Pendidikan & Frekuensi & $\begin{array}{l}\text { Persentase } \\
(\mathbf{\%})\end{array}$ \\
\hline $\mathbf{1}$ & Tidak Tamat & 17 & 20 \\
$\mathbf{2}$ & SD & 37 & 41.2 \\
$\mathbf{3}$ & SMP & 11 & 12.9 \\
$\mathbf{4}$ & SMA & 21 & 23.5 \\
$\mathbf{5}$ & PT & 2 & 2.4 \\
\hline & Jumlah & 85 & 100 \\
\hline
\end{tabular}

Hasil Penelitian menunjukkan bahwa sebagian besar pendidikan responden adalah SD dengan jumlah sebanyak 37 orang (41.2\%).

\section{Pekerjaan}

\begin{tabular}{llll}
$\begin{array}{l}\text { Tabel 5. Distribusi Frekuensi } \\
\text { Responden }\end{array}$ & Pekerjaan \\
\hline No & Pekerjaan & Frekuensi & $\begin{array}{l}\text { Persentase } \\
(\%)\end{array}$ \\
\hline $\mathbf{1}$ & & & 48.2 \\
$\mathbf{2}$ & Petani & 41 & 27.1 \\
$\mathbf{3}$ & IRT & 23 & 18.8 \\
$\mathbf{4}$ & Wiraswasta & 16 & 5.9 \\
$\mathbf{5}$ & Pelajar & 5 & 0 \\
\hline & PNS & 0 & 100 \\
\hline & Jumlah & 85 & \\
\hline
\end{tabular}

Berdasarkan hasil dari penelitian pada tabel 5 terlihat bahwa dari 85 responden yang diteliti, sebagian besar pekerjaan dari responden adalah Petani dengan jumlah 41 orang $(48.2 \%)$.

\section{Pengetahuan}

Tabel 6. Distribusi Frekuensi Pengetahuan Responden

\begin{tabular}{llll}
\hline No & Pengetahuan & Frekuensi & $\begin{array}{l}\text { Persentase } \\
(\boldsymbol{\%})\end{array}$ \\
\hline $\mathbf{1}$ & Kurang Baik & 25 & 29.4 \\
$\mathbf{2}$ & Baik & 60 & 70.1 \\
\hline & Jumlah & 85 & 100 \\
\hline
\end{tabular}

Berdasarkan hasil dari penelitian pada tabel 6 terlihat bahwa dari 85 responden yang diteliti, sebagian besar pengetahuan responden tentang gigi tiruan berada dalam kategori baik dengan jumlah sebanyak 60 orang $(70.1 \%)$.

Sikap

Tabel 7. Distribusi Frekuensi Sikap Responden

\begin{tabular}{llll}
\hline No & Pengetahuan & Frekuensi & $\begin{array}{l}\text { Persentase } \\
(\boldsymbol{\%})\end{array}$ \\
\hline $\mathbf{1}$ & Kurang Baik & 37 & 43.6 \\
$\mathbf{2}$ & Baik & 48 & 65.4 \\
\hline & Jumlah & 85 & 100 \\
\hline
\end{tabular}


Berdasarkan hasil dari penelitian pada tabel 7 terlihat bahwa dari 85 responden yang diteliti, sikap responden tentang gigi tiruan berada dalam kategori baik dengan jumlah sebanyak 48 orang $(65.4 \%)$.

\section{Tindakan}

Tabel 8. Distribusi Frekuensi Tindakan Responden

\begin{tabular}{llll}
\hline No & Tindakan & Frekuensi & $\begin{array}{l}\text { Persentase } \\
(\boldsymbol{\%})\end{array}$ \\
\hline $\mathbf{1}$ & $\begin{array}{l}\text { Kurang } \\
\text { Baik }\end{array}$ & 40 & 47.1 \\
$\mathbf{2}$ & Baik & 45 & 52.9 \\
\hline & Jumlah & 85 & 100 \\
\hline
\end{tabular}

Berdasarkan hasil penelitian dari 85 responden seperti yang yang terlihat pada tabel 8 bahwa lebih banyak tindakan masyarakat yang baik dengan jumlah 45 orang $(52.9 \%)$.

\section{PEMBAHASAN}

\section{Gigi Tiruan}

Berdasarkan hasil penelitian bahwa didapatkan informasi dari 85 orang responden yang diteliti, sebagian besar responden tidak memakai gigi tiruan dengan jumlah 78 orang (91.8\%), sedangkan yang memakai gigi tiruan berjumlah 7 orang $(8.2 \%)$.

Pada penelitian yang dilakukan Monalisa pada tahun 2019 di Desa Bandur Picak Kecamatan Koto Kampar Hulu Kabupaten Kampar menunjukkan yaitu lebih banyak responden yang tidak memakai gigi tiruan dibandingkan yang memakai. Dari 95 responden yang diteliti, sebagian besar responden tidak memakai gigi tiruan yaitu 66 orang responden (69.5\%), sedangkan yang memakai gigi tiruan hanya 29 orang ( $30.5 \%$ ).

Menurut Haryanto, 1991 Gigi tiruan adalah salah satu alat yang menggantikan bagian gigi geligi yang hilang yang dapat memperbaiki fungsi pengunyahan, fungsi estetik, fungsi bicara serta dapat meningkatkan derajat kesehatan seseorang

Hasil penelitian yang dilakukan di Dusun I Desa Talikumain menunjukkan bahwa masih sangat banyak masyarakat yang tidak menggunakan gigi tiruan untuk menggantikan gigi yang hilang. Padahal, pengetahuan yang mereka miliki cukup baik. Peneliti berasumsi hal tersebut dikarenakan masyarakat masih menganggap bahwa gigi palsu bukanlah kebutuhan pokok sehingga tidak perlu digunakan. Selain itu, juga disebabkan karena mereka belum merasakanatau mengalami akibat dari kehilangan gigi yang tidak digantikan.

\section{Umur}

Berdasarkan hasil penelitian terlihat bahwa dari 95 orang responden yang diteliti, sebagian besar umur responden masuk kedalam kategori lansia awal (46- 55 tahun) berjumlah 27 responden (31.8\%), sedangkan terendah responden masuk dalam kategori manula berjumlah $7(8,2 \%)$.

Hasil RISKESDAS tahun 2007 melaporkan bahwa, kehilangan gigi ditemukan pada kelompok 45-54 tahun sebesar 1,8\%, 55-64 tahun sebesar 5.9\%, dan pada kelompok umur 65 tahun keatas kehilangan gigi mencapai $17.6 \%$.

Hal ini didukung oleh teori Notoatmodjo (2007) bahwa umur adalah mempengaruhi daya tanggap dan pola pikir seseorang. Semakin bertambah umur semakin berkembang pula daya tangkap dan pola pikirnya, sehingga pengetahuan yang diperoleh semakin membaik.

Berdasarkan hasil penelitian yang dilakukan di Dusun I Desa Talikumain maka peneliti berasumsi bahwa pada umur lansia awal mereka tidak mementingkan penampilan (estetik), mereka tidak merasa malu atau minder apabila tidak memakai gigi tiruan hal itu disebabkan karena menurut mereka pengantian gigi yang sudah lepas bukanlah hal yang penting. Pendapat 
merekadisebabkan karena kurangnya pengetahuan mereka tentang pentingnya pemakaian gigi tiruan sebagai penganti gigi yang hilang. Diharapkan kepada tenaga kesehatan untuk mengadakan sosialisasi kepada masyarakat Dusun I Desa Talikumain tentang pentingnya pemakaian gigi tiruan, tidak hanya untuk usia lansia awal saja melainkan pada semua usia bagi mereka yang kehilangan gigi.

\section{Jenis Kelamin}

Berdasarkan hasil penelitian terlihat bahwa dari 85 orang responden yang diteliti, bahwa sebagian besar jenis kelamin responden adalah perempuan yaitu 58 responden (68.2\%), sedangkan terendah laki-laki 27 orang (31.8\%).

Berdasarkan hasil penelitian yang dilakukan oleh American Dental Association melaporkan bahwa resiko perempuan mengalami penyakit mulut lebih tinggi dibandingkan laki-laki karena perempuan pada umumnya mengalami kondisi menstruasi, kehamilan dan menopause dimana pada saat itu hormon estrogen meningkat kerapuhan gigi dan peradangan sehingga persentase pada kehilangan gigi pada perempuan lebih tinggi.

Faktor jenis kelamin merupakan suatu variable deskriptif yang dapat memberikan angka kejadian pada pria dan wanita. Didalam metode penelitian, jenis kelamin mempengaruhi karakteristik responden untuk mengetahui pengetahuan, sikap, dan sebagainya terhadap suatu objek yang diteliti. Berdasarkan hasil penelitian yang dilakukan di Dusun I Desa Talikumain maka peneliti berasumsi bahwa perempuan lebih banyak kehilangan gigi disebabkan karena perempuan lebih banyak mengalami penyakit mulut dikarenakan faktor hormone.

\section{Pendidikan}

Dari hasil penelitian bahwa dari 85 orang responden yang di teliti, sebagian besar pendidikan responden yaitu SD berjumlah 37 orang (41.2\%) dan paling sedikit yaitu lulusan perguruan tinggi berjumlah 2 orang $(2.4 \%)$.

Penelitian ini sejalan dengan penelitian yang dilakukan oleh Monalisa (2018). Berdasarkan hasil penelitian yang dilakukan oleh Monalisa sebagian besar subjek penelitian berpendidikan tingkat SD 25 orang $(86,2 \%)$.

Pendidikan berati bimbingan yang diberikan seseorang terhadap perkembangan orang lain menunjuk kearah cita- cita tertentu yang menentukan manusia untuk berbuat dan mengisi kehidupan untuk mencapai keselamatan dan kebahagiaan. Pendidikan diperlukan untuk mendapatkan informasi misalnya hal-hal yang menunjang kesehatan sehingga dapat meningkatkan kualitas hidup. Pendidikan dapat mempengaruhi seseorang termasuk juga perilaku seseorang akan pola hidup terutama dalam memotivasi untuk sikap berperan serta dalam pembangunan (Nursalam, 2003) pada umumnya makin tinggi pendidikan seseorang makin mudah menerima informasi.

Berdasarkan hasil penelitian yang dilakukan di Dusun I Desa Talikumain maka peneliti berasumsi jika tingginya tingkat pendidikan SD dikarenakan disana rata-rata masyarakat memang hanya berpendidikan sampai tamat SD. Menurut peneliti hal tersebut dikarenakan masih rendahnya informasi atau pengetahuan masyarakat yang rata-ratanya hanya berpendidikan hanya sampai tingkat Sekolah Dasar. Diharapkan kepada tenaga kesehatan untuk melakukan sosialisasi kepada para penduduk tentang pentingnya pemakaian gigi tiruan tiruan pada masyarakat di Dusun I Desa Talikumain bukan hanya yang berpendidikan SD saja tapi untuk semua masyarakat.

\section{Pekerjaan}

Dari hasil penelitian terlihat bahwa dari 85 orang responden yang diteliti, 
sebagian besar pekerjaan dari responden yaitu 41 orang (48.2\%), sedangkan terendah PNS karena tidak ada responden yang bekerja sebagai PNS.

Penelitian ini sejalan dengan penelitian yang dilakukan oleh Monalisa (2018). Berdasarkan hasil penelitian yang dilakukukan oleh Monalisa sebagian besar subjek penelitian sebagai petani 68 orang $(71.6 \%)$.

Menurut Thomas yang dikutip oleh Nursalam (2003), pekerjaan adalah keburukan yang harus dilakukan terutama untuk menunjang kehidupannya dan kehidupan keluarga. Pekerjaan bukanlah sumber kesenangan, tetapi lebih banyak merupakan cara mencari nafkah yang membosankan, berulang dan banyak tantangan. Sedangkan bekerja umunya merupakan kegiatan yang menyita waktu.

Menurut asumsi peneliti, sebagian besar responden yang tidak menggunakan gigi tiruan bekerja sebagai petani disebabkan karena mereka tidak membutuhkan estetik yang bagus dalam bekerja.

\section{Pengetahuan}

Dari hasil penelitian dari 85 orang responden, maka diperoleh hasil responden dengan pengetahuan baik berjumlah 60 orang (70.6\%). Adapun responden dengan pengetahuan yang kurang baik berjumlah 25 orang (29.4\%).

Penelitian ini sejalan dengan penelitian yang dilakukan oleh Chairunnisa dkk yang menyatakan bahwa lebih banyak responden yang pengetahuannya baik. Berdasarkan penelitian Chairunnisa dkk pengetahuan masyarakat tentang pemakaian gigi tiruan di Kecamatan Jaya Baru Banda Aceh masyarakat yang memiliki pengetahuan dengan kategori baik sebanyak 181 orang $(67.0 \%)$, sedang sebanyak 65 orang $(24.1 \%)$ dan kategori buruk sebanyak 24 orang $(8.9 \%)$ dari 270 orang sampel.

Pengetahuan adalah hasil pengindraan manusia, atau hasil tahu seseorang terhadap objek melalui indra yang dimilikinya (mata, hidung, telinga, dan sebagainya). Dengan sendirinya pada waktu pengindraan sehingga menghasilkan pengetahuan tersebut sangat dipengaruhi oleh intensitas perhatian dan persepsi terhadap objek. Sebagian besar pengetahuan seseorang diperoleh melalui indra pendengaran (telinga), dan indra penglihatan (mata).

Berdasarkan hasil penelitian masyarakat di Dusun I Desa Talikumain memiliki pengetahuan yang baik mengenai mengenai gigi tiruan. Peneliti berasumsi bahwa pengetahuan tersebut mereka peroleh dari media massa seperti televisi dan media sosial lainnya.

\section{Sikap}

Hasil penelitian dari 85 orang responden terlihat responden yang bersifat baik berjumlah 48 orang (56.4\%). Adapun responden dengan sikap yang kurang baik berjumlah 37 orang (43.6\%).

Berdasarkan hasil penelitian yang dilakukan Harsanti (2017), menunjukkan bahwa mayoritas responden bersikap baik dalam memelihara gigi tiruan sebanyak 76 responden $(98.7 \%)$.

Sikap adalah respon tertutup seseorang terhadap stimulus atau objek tertentu, yang sudah melibatkan faktor pendapat dan emosi yang bersangkutan (senang - tidak senang, setuju - tidak setuju, baik - tidak baik, dan sebagainya).

Menurut asumsi peneliti masyarakat Dusun I Desa Talikumain memiliki sikap yang tidak baik, tetapi mengapa hasil penelitian sikap masyarakat tentang gigi tiruan di Dusun I Desa Talikumain baik disebabkan karena sebagian mereka sudah mengetahui tentang pentingnya penggunaan gigi tiruan hanya saja mereka belum memiliki kesadaran untuk melakukan pembuatan gigi tiruan.

\section{Tindakan}

Dari hasil penelitian 85 orang responden, maka diperoleh hasil responden dengan tindakan baik yaitu 45 
orang $(52.9 \%)$. Adapun responden dengan tindakan kurang baik berjumlah 40 orang $(47.1 \%)$.

Berdasarkan hasil penelitian yang dilakukan Harsanti (2017), menunjukkan bahwa 77 responden mayoritas baik dalam perilaku memelihara gigi tiruan sebanyak 77 responden (100\%).

Tindakan adalah seseorang yang mengetahui stimulus atau objek kesehatan, kemudian mengadakan penilaian atau pendapat terhadap apa yang diketahui, proses selanjutnya melaksanakan atau mempratikkan apa yang diketahui atau disikapinya (Notoatmodjo, 2012).

Menurut asumsi peneliti, belum baiknya tindakan masyarakat terhadap pemakaian gigi tiruan karena mereka beranggapan bahwa tanpa menngunakan gigi palsupun, tidak ada aktifitas mereka yang terganggu. Hal tersebut juga dikarenakan belum adanya dampak yang mereka alami akibat tidak memakai gigi tiruan.

\section{KESIMPULAN}

Berdasarkan hasil penelitian tentang Gambaran Perilaku Masyarakat Tentang Pentingnya Pemakaian Gigi Tiruan Di Dusun I Desa Talikumain Kecamatan Tambusai Tengah Kabupaten Rokan Hulu Tahun 2019 dan setelah dilakukan pembahasan maka penulis dapat mengambil kesimpulan sebagai berikut :

1. Dari 85 orang mayoritas responden yang tidak memakai gigi tiruan sebanyak 78 orang $(91.8 \%)$.

2. Dari 85 orang responden mayoritas responden masuk dalam kategori lansia awal (46-55 tahun) berjumlah 27 responden $(31.8 \%)$.

3. Dari 85 orang responden mayoritas sebagian besar berjenis kelamin perempuan yaitu 58 responden $(68.2 \%)$

4. Dari 85 orang responden mayoritas pendidikan responden terbanyak SD berjumlah 37 orang $(41.2 \%)$.
5. Dari 85 orang responden mayoritas pekerjaan responden terbanyak yaitu petani yaitu 41 orang $(48.2 \%)$.

6. Sebagian besar pengetahuan masyarakat tentang gigi tiruan tergolong baik, dengan jumlah 60 orang $(70.6 \%)$

7. Sikap masyarakat tentang gigi tiruan baik berjumlah 48 orang (56.4\%).

8. Tindakan masyarakat tentang gigi tiruan baik berjumlah 45 orang $(52.9 \%)$.

\section{DAFTAR PUSTAKA}

A. Wawan dan Dewi, (2010). Teori dan Pengukuran Pengetahuan Sikap dan Perilaku Manusia. Yogyakarta: NuhaMedika

Achmadi .U .F. (2013). Kesehatan Masyarakat Teori dan Aplikasi. Jakarta: PT RajaGrafindoPersada

Chairunnisa dkk. (2017). Gambaran Tingkat Pengetahuan Masyarakat Tentang Kehilangan Gigi Dan Pemakaian Gigi Tiruan Di Kecamatan Jaya Baru Banda Aceh. http:www.jim.unsyiah.ac.id/JCD/arti

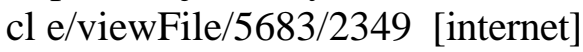
diakses November 2019.

Gunandi, H.A.dkk. (1991). Buku Ajar Ilmu Geligi Tiruan Sebagian Lepasan Jilid I. Jakarta: Hipokrates

Martono N. (2011). Metode Penelitian Kuantitatif Analisis Isi dan Analisis Data Sekunder. Jakarta: PT Raja GrafindoPersada

Monalisa. (2018). Gambaran Pengetahuan dan Sikap Masyarakat Terhadap Pemakain Gigi Tiruan Di Desa Bandur Kecamatan Koto Kampar Hulu Kabupaten Kampar Tahun 2018. Disertai tidak diterbitkan. 
Program D III Teknik Gigi.

Pekanbaru

Notoatmodjo, Soekidjo (2012).

Metodologi Penelitian Kesehatan.

Jakarta: RinekaCipta.

Notoatmodjo, Soekidjo (2010). Promosi Kesehatan Teori \& Aplikasi.

Jakarta:RinekaCipta
Situni J.L. (2013). Identifikasi

Faktor Penghambat Seseorang Menggunakan Gigi Tiruan. Program Studi Kedokteran Gigi Fakultas Kedokteran Universitas Sam Ratulangi Manado. [internet] http://ejournal.unsrat.ac.id/index.php le gigi/article/download/3212/2753

Wiratna V.S. (2014). Metode Penelitian. Yogyakarta:PUSTAKABARUPRESS 